\title{
ANALISIS PERBANDINGAN POTENSI PENERIMAAN DAN EFEKTIFITAS PAJAK PENERANGAN JALAN KABUPATEN MINAHASA SELATAN DAN KABUPATEN MINAHASA TENGGARA
}

\author{
Driyana Ibrahim ${ }^{1}$ \\ Jullie J Sondakh ${ }^{2}$ \\ Anneke Wangkar ${ }^{3}$ \\ ${ }^{123}$ Fakultas Ekonomi dan Bisnis, Jurusan Akuntansi \\ Universitas Sam Ratulangi Manado \\ Dryanaibrahim@yahoo.com \\ Julliesondakh@yahoo.com \\ Annekewangkar@yahoo.com
}

\begin{abstract}
In an effort to improve the implementation of development and service to the community as well as increased economic growth in the region, the one source of regional revenue from tax sector in particular, is the street lighting tax. In accordance with Law No. 28 of 2009 Article 1 number 28, street lighting tax (RPM) is a tax on the use of electricity, either generated themselves or obtained from other sources. The purpose of this study was to determine the level comparison of the revenue potential and effectiveness of street lighting tax in South Minahasa District and Southeast Minahasa Regency 2011 2015. This research was conducted in South Minahasa District DPPKAD and DISPENDA Southeast Minahasa Regency. The analytical method used was descriptive qualitative method. Based on the results of this study concluded that there are differences in the potential of street lighting tax receipts between the South Minahasa District and Southeast Minahasa Regency in the years 2011-2015, but there was no difference in the effectiveness of street lighting tax receipts between the South Minahasa District and Southeast Minahasa Regency 2011-2015. Street lighting tax revenue as one of the biggest areas in the South Minahasa District and Southeast Minahasa Regency is expected to be a mobilizer of local taxes in the regencies of them.
\end{abstract}

Keywords: street lighting tax, potential, effectiveness.

\section{Latar Belakang}

\section{PENDAHULUAN}

Untuk menjadi daerah otonom, suatu daerah harus mempunyai kemampuan ekonomi yang memadai agar jalannya pemerintah tidak tersendat-sendat dan pembangunan dapat terlaksana dengan baik, di sisi lain Negara Indonesia merupakan salah satu Negara yang menjunjung tinggi atas hak dan kewajiban untuk setiap orang berdasarkan Pancasila dan UUD 1945, maka dari itu dalam menempatkan pajak sebagai suatu perwujudan kewajiban kenegaraan untuk gotong-royong nasional, yang merupakan peran pemerintah serta masyarakat dalam pembiayaan pembangunan (Purwasih, 2014).

Berdasarkan Undang-Undang Nomor 23 Tahun 2014 tentang Pemerintahan Daerah dan UndangUndang Nomor 33 Tahun 2004 tentang Perimbangan Keuangan antara Pemerintah Pusat dan Daerah, Anggaran Pendapatan dan Belanja Daerah antara lain bersumber dari Pendapatan Asli Daerah berupa Pajak Daerah yang merupakan salah satu sumber pembiayaan penyelenggaraan pemerintahan dan pembangunan daerah untuk meningkatkan kesejahteraan masyarakat.Dalam upaya meningkatkan pelaksanaan pembangunan dan pelayanan pada masyarakat serta peningkatan pertumbuhan ekonomi di daerah, maka salah satu sumber Pendapatan Daerah khususnya dari sektor Pajak yaitu Pajak Penerangan 
Jalan sebagai konsekuensi logis dari penetapan ketentuan Undang-Undang Pajak Daerah dan Retribusi Daerah yang baru dalam kaitannya dengan peningkatan kinerja pemungutan.

Meningkatkan efektivitas Pemungutan Pajak Penerangan Jalan merupakan salah satu jalan keluar untuk meningkatkan pendapatan asli daerah.(Manongga, 2014). Upaya yang dapat dilakukan oleh pemerintah daerah untuk meningkatkan Pendapatan Asli Daerah (PAD) yaitu dengan intensifikasi yang salah satunya adalah dengan menggali sumber-sumber pendapatan baru yang potensinya dimungkinkan untuk dipungut pajak. Disamping itu perlu adanya peningkatan sarana dan prasarana wilayah serta kualitas pembangunan yang berorientasi pada pemerataan, agar sumber dana dan sumber daya yang tersedia dapat dimanfaatkan seefisien dan seefektif mungkin. Daerah dituntut untuk meningkatkan PAD dengan memaksimalkan potensi daerah yang tersedia dan memungkinkan untuk dipungut pajak (Pratama, 2014).

Data penerimaan PAD Kabupaten Minahasa Selatan dan Kabupaten Minahasa Tenggara dapat dilihat pada tabel berikut ini.

Tabel 1.Penerimaan PAD Kabupaten Minahasa Selatan dan Kabupaten Minahasa TenggaraTahun 2011-2014

\begin{tabular}{lcc}
\hline Tahun & Kabupaten Minahasa Selatan & Kabupaten Minahasa Tenggara \\
\hline 2011 & Rp. 9.407 .280 .004 & Rp. 4.959.574.921 \\
\hline 2012 & Rp. 10.620 .087 .945 & Rp. 5.000.000.000 \\
\hline 2013 & Rp. 14.406.092.809 & Rp. 7.683.748.533 \\
\hline 2014 & Rp. 26.137.234.620 & Rp. 13.401.994.880
\end{tabular}

Sumber: Buku Putih Sanitasi Kabupaten Minahasa Selatan dan Minahasa Tenggara

Tabel 1 menunjukkan bahwa penerimaan PAD setiap tahunnya mengalami peningkatan dari tahun 2011-2014.Sumber Pendapatan Asli Daerah khususnya dari sektor pajak yaitu Pajak Penerangan Jalan. Berdasarkan tabel diatas maka menarik untuk dikaji masalah-masalah berikut: bagaimana potensi penerimaan dan efektivitas pajak penerangan jalan di Kabupaten Minahasa Selatan dan Kabupaten Minahasa Tenggara? Tujuan dari penelitian ini yaitu untuk mengetahui potensi penerimaan dan efektivitas Pajak Penerangan Jalan di Kabupaten Minahasa Selatan dan Kabupaten Minahasa Tenggara, serta mengetahui perbandingan potensi penerimaan dan efektivitas pajak penerangan jalan Kabupaten Minahasa Selatan dengan Kabupaten Minahasa Tenggara tahun 2011-2015.

Dalam mengestimasi potensi PAD, diperlukan informasi dan tolak ukur yang riil terjadi di lapangan dan secara konkrit dikehendaki oleh masyarakat di daerah. Salah satu tolak ukur finansial yang dapat digunakan untuk melihat kesiapan daerah dalam pelaksanaannya adalah dengan mengukur seberapa jauh kemampuan keuangan suatu daerah. Salah satunya adalah dengan mengoptimalkan hasil pajak daerah yang sudah ada (Wurangian, 2013).

\section{Tujuan Penelitian}

Dengan latar belakang tersebut, adapun tujuan dari penelitian ini adalah sebagai berikut:

1. Mengetahui potensi penerimaan pajak penerangan jalan di Kabupaten Minahasa Selatan dan Kabupaten Minahasa Tenggara

2. Mengetahui efektivitas pajak penerangan jalan di Kabupaten Minahasa Selatan dan Kabupaten Minahasa Tenggara

3. Mengetahui perbandingan potensi penerimaan pajak penerangan jalan Kabupaten Minahasa Selatan dengan Kabupaten Minahasa Tenggara tahun 2011-2015 
4. Mengetahui perbandingan efektivitas penerimaan pajak penerangan jalan Kabupaten Minahasa Selatan dengan Kabupaten Minahasa Tenggara tahun 2011-2015

\section{Definisi Akuntansi}

\section{Tinjauan Pustaka}

Menurut Suwardjono (2014:5), akuntansi adalah seni pencatatan, penggolongan, dan peringkasan transaksi dan kejadian yang bersifat keuangan dengan cara yang berdaya guna dan dalam bentuk satuan uang, dan penginterpretasian hasil proses tersebut. Seni dalam definisi tersebut untuk menunjukkan bahwa akuntansi bukan merupakan ilmu pengetahuan eksakta atau sains karena dalam proses penalaran dan perancangan, akuntansi banyak terlibat unsur pertimbangan (judgment).

\section{Akuntansi Perpajakan}

Dalam menetapkan besarnya pajak terutang tetap mendasarkan laporan keuangan yang disusun oleh perusahaan, mengingat dalam ketentuan perundang-undangan perpajakan terdapat aturan-aturan khusus yang berkaitan dengan akuntansi, yaitu masalah konsep transaksi dan peristiwa keuangan, metode pengukurannya, serta pelaporannya yang ditetapkan dengan undang-undang (Waluyo 2012:34).

\section{Pengertian Pajak}

Menurut Sumarsan (2011:3), pajak adalah bantuan, baik secara langsung maupun tidak langsung yang dipaksakan oleh kekuasaan publik dari penduduk atau dari barang, untuk menutupi belanja pemerintah. Artinya pajak merupakan suatu pemungutan dari masyarakat yang berguna untuk kepentingan Negara.

\section{Pengertian Pajak Daerah}

Menurut Undang-Undang Republik Indonesia No. 28 Tahun 2009 Pajak Daerah, yang selanjutnya disebut Pajak, adalah kontribusi wajib kepada Daerah yang terutang oleh orang pribadi atau badan yang bersifat memaksa berdasarkan Undang-Undang, dengan tidak mendapatkan imbalan secara langsung dan digunakan untuk keperluan Daerah bagi sebesar-besarnya kemakmuran rakyat.

\section{Pajak Penerangan Jalan}

Undang - Undang No. 28 Tahun 2009 tentang Pajak Daerah dan Retribusi Daerah, pajak penerangan jalan adalah pajak atas penggunaan tenaga listrik, baik yang dihasilkan sendiri, maupun diperoleh dari sumber lain. Pengertian Pajak Penerangan Jalan menurut Peraturan Daerah Kabupaten Minahasa Selatan No. 10 Tahun 2005 Tentang Pajak Daerah, pajak penerangan jalan adalah pajak yang dipungut atas setiap penggunaan tenaga listrik.

\section{Objek Pajak Penerangan Jalan}

Menurut Peraturan Daerah (Perda) Kabupaten Minahasa Selatan Nomor 10 Tahun 2005 Tentang Pajak Penerangan Jalan sebagai objek Pajak Penerangan Jalan adalah penggunaan tenaga listrik, baik yang dihasilkan sendiri maupun yang diperoleh dari sumber lain.

\section{Perhitungan Potensi Penerimaan Pajak Penerangan Jalan}

Dengan rumus sebagai berikut: Setelah diketahui basis pajaknya, kemudian dapat dihitung potensi pajak penerangan jalan dengan rumus:

Basis Pajak PPJ = Biaya Beban + Biaya Pemakaian

$$
\text { Listrik }
$$

Sumber: Hamrolie, 2003 
Setelah diperoleh basis pajaknya, kemudian potensi penerimaan Pajak Penerangan Jalan dapat digunakan rumus sebagai berikut:

Potensi PPJ = Basis Pajak Penerangan Jalan $\times$ Tarif

Pajak

Sumber: Hamrolie, 2003

Sehingga, semakin besar hasil perhitungan potensi yang dinyatakan dalam bentuk persentase berarti menunjukan potensi pajak penerangan jalan yang dimiliki juga besar (Indrakusuma, 2011).

\section{Perhitungan Efektivitas Pajak Penerangan Jalan}

Efektivitas berkaitan dengan pencapaian tujuan dengan biaya layak (reasonable) dalam kaitannya dengan nilai dari sebuah hasil (outcome).Bahkan efektivitas juga diukur dengan mempertimbangkan akibat atau hasil yang diharapkan atau tidak diharapkan (Aryanto, 2005). Dalam penelitian ini rumus penghitungan efektivitas yang digunakan adalah sebagai berikut:

$$
\text { Efektivitas }=\frac{\text { Realisasi Penerimaan Pajak }}{\text { Target Penerimaan Pajak }} \times 100 \%
$$

Sumber: Simanjuntak, 2001

\section{Jenis Penelitian}

\section{Metode Penelitian}

Penelitian ini menggunakan metode penelitian deskriptif yaitu berupa studi kasus dan studi pustaka.Studi kasus dilakukan pada Dinas Pengelola Kuangan, Pendapatan dan Aset Daerah.Sedangkan studi pustaka dilakukan dengan mengumpulkan data-data dari literatur-literatur yang relevan dengan analisis potensi dan efektivitas Pajak Penerangan Jalan (PPJ).

\section{Tempat Penelitian dan Waktu Penelitian}

Pemilihan lokasi yang dilakukan dalam penilitian ini adalah pada Kantor Dinas Pengelola Keuangan, Pendapatan, Dan Aset Daerah (DPPKAD) yang berkedudukan di Jalan Trans Sulawesi, Kelurahan Pondang, Kecamatan Amurang Timur, Kabupaten Minahasa Selatan, dan Kantor Dinas Pendapatan Daerah (DISPENDA) Kabupaten Minahasa Tenggara yang berlokasi di Jalan Raya Ratahan Belang Blok A Kelurahan Pasan - Wawali Kecamatan Ratahan Kabupaten Minahasa Tenggara. Waktu Penelitian dilaksanakan pada bulan Februari-April 2016.

\section{Prosedur Penelitian}

1. Menentukan judul dan merumuskan masalah.

2. Mengumpulkan data sesuai permasalahan yang diangkat.

3. Pengumpulan data melalui wawancara terhadap pihak-pihak yang terkait.

4. Mengelola data dan menginterpretasikan hasil pengolahan data.

5. Menarik kesimpulan dan memberikan saran.

\section{Metode Pengumpulan Data}

1. Jenis Data

a. Data kualitatif

b. Data kuantitatif

2. Sumber Data
a. Data primer
b. Data Sekunder

\section{Teknik Pengumpulan Data}


1. Metode Wawancara

2. Metode Dokumentasi

3. Media Elektronik dan Media Buku

\section{Metode Analisis}

Metode yang digunakan untuk menganalisis data adalah metode deskriptif yaitu metode yang digunakan untuk menggambarkan atau menganalisis suatu hasil penelitian tetapi tidak digunakan untuk menggunakan kesimpulan yang lebih luas (Sugiyono 2011:21).

\section{HASIL PENELITIAN DAN PEMBAHASAN}

\section{Hasil Penelitian}

1. Perkembangan Pajak Penerangan Jalan di Kabupaten Minahasa Selatan

Untuk mengetahui perkembangan pajak penerangan jalan di Kabupaten Minahasa Selatan dapat dilihat dari data Target dan Realisasi Pajak Penerangan Jalan Kabupaten Minahasa Selatan dalam tahun anggaran 5 (lima) tahun terakhir yaitu tahun 2011-2015 yang telah diperoleh peneliti dalam penelitian lapangan di Kantor Dinas Pengelola Keuangan, Pendapatan dan Aset Daerah Kabupaten Minahasa Selatan, yang disajikan dalam tabel berikut ini:

Tabel 2. Target dan Realisasi Penerimaan Pajak Penerangan Jalan Kabupaten Minahasa Selatan Tahun 2011-2015

\begin{tabular}{lcccc}
\hline No & Tahun Anggaran & Target $(\mathrm{Rp})$ & Realisasi $(\mathrm{Rp})$ & Ket \\
\hline 1 & 2011 & 2.800 .000 .000 & 3.340 .811 .055 & Naik \\
\hline 2 & 2012 & 2.700 .000 .000 & 3.653 .605 .865 & Naik \\
\hline 3 & 2013 & 4.837 .200 .000 & 4.284 .764 .894 & Naik \\
\hline 4 & 2014 & 4.837 .200 .000 & 4.394 .767 .360 & Naik \\
\hline 5 & 2015 & 4.837 .200 .000 & 4.831 .945 .337 & Naik \\
\hline $\begin{array}{l}\text { Sumber: Dinas Pengelola Keuangan, Pendapatan, dan Aset Daerah Kabupaten Minahasa } \\
\text { Selatan }\end{array}$
\end{tabular}

Dari tabel 2 dapat dilihat target dan realisasi penerimaan pajak penerangan jalan selama 5 (lima) tahun anggaran 2011-2015 mengalami peningkatan setiap tahun, yaitu pada tahun 2011 target Rp. 2.800.000.000 realisasi 3.340.811.055, tahun 2012 target Rp. 2.700.000.000 realisasi Rp. 3.653.605.865, tahun 2013 target Rp. 4.837.200.000 realisasi Rp. 4.284.764.894, tahun 2014 target Rp. 4.837.200.000 realisasi Rp. 4.394.767.360, tahun 2015 target Rp. 4.837.200.000 realisasi Rp. 4.831.945.337.

\section{Perkembangan Pajak Penerangan Jalan di Kabupaten Minahasa Tenggara}

Untuk mengetahui perkembangan pajak penerangan jalan di Kabupaten Minahasa Tenggara dapat dilihat dari data Target dan Realisasi Pajak Penerangan Jalan Kabupaten Minahasa Tenggara dalam tahun anggaran 5 (lima) tahun terakhir yaitu tahun 2011-2015 yang telah diperoleh peneliti dalam penelitian lapangan di Kantor Dinas Pendapatan Daerah Kabupaten Minahasa Tenggara, yang disajikan dalam tabel berikut ini:

Tabel 3. Target dan Realisasi Penerimaan Pajak Penerangan JalanKabupaten Minahasa Tenggara Tahun 2011-2015

\begin{tabular}{llll}
\hline No & Tahun Anggaran & Target (Rp) & Realisasi $(\mathrm{Rp})$
\end{tabular}




\begin{tabular}{lllll}
\hline 1 & 2011 & 660.000 .000 & 834.227 .435 & Naik \\
\hline 2 & 2012 & 750.000 .000 & 1.052 .193 .695 & Naik \\
\hline 3 & 2013 & 900.000 .000 & 1.032 .959 .466 & Naik \\
\hline 4 & 2014 & 900.000 .000 & 1.192 .772 .391 & Naik \\
\hline 5 & 2015 & 1.904 .803 .992 & 2.138 .933 .316 & Naik \\
\hline \multicolumn{5}{l}{ Sumber: Dinas Pendapatan Daerah Kabupaten Minahasa Tenggara } \\
\end{tabular}

Dari tabel 3 dapat dilihat target dan realisasi penerimaan pajak penerangan jalan selama 5 (lima) tahun anggaran 2011-2015 mengalami peningkatan setiap tahun, yaitu pada tahun 2011 target Rp. 660,000,000 realisasi Rp. 834,227,435, tahun 2012 target Rp. 750,000,000 realisasi Rp. 1,052,193,695, tahun 2013 target Rp. 900.000.000 realisasi Rp. 1.032.959.466, tahun 2014 target Rp. 900.000.000 realisasi Rp. 1.192.772.391, tahun 2015 target Rp. 1,904,803,992 realisasi Rp. 2,138,933,316.

\section{Biaya Beban dan Biaya Pemakaian Listrik Pajak Penerangan Jalan Kabupaten Minahasa} Selatan per Golongan Tarif Rumah Tangga, Bisnis, dan Industri

Untuk mengetahui basis pajak penerangan jalan di Kabupaten Minahasa Selatan dapat dilihat dari data Biaya Beban dan Biaya Pemakaian Listrik Pajak Penerangan Jalan Kabupaten Minahasa Selatan per Golongan Tarif dalam 5 (lima) tahun terakhir yaitu tahun 2011-2015 yang telah diperoleh peneliti dalam penelitian lapangan di Kantor PLN Cabang Amurang, yang disajikan dalam tabel berikut ini:

Tabel 4. Biaya Beban dan Biaya Pemakaian Listrik Pajak Penerangan Jalanper Golongan Tarif Rumah Tangga dan Bisnis Tahun 2011-2015

\begin{tabular}{lccc}
\hline No & Tahun Anggaran & Biaya Beban $(\mathrm{Rp})$ & Biaya Pemakaian Listrik $(\mathrm{Rp})$ \\
\hline 1 & 2011 & 188.896 .628 & 27.810 .817 .224 \\
\hline 2 & 2012 & 177.664 .860 & 22.688 .012 .496 \\
\hline 3 & 2013 & 167.498 .025 & 26.769 .037 .104 \\
\hline 4 & 2014 & 169.856 .201 & 36.329 .306 .172 \\
\hline 5 & 2015 & 152.120 .205 & 37.303 .214 .916 \\
\hline Sumber: PLN Cabang Amurang & &
\end{tabular}

Dari tabel 4 dapat dilihat biaya beban dan biaya pemakaian listrik pajak penerangan jalan per Golongan tarif Rumah Tangga dan Bisnis selama 5 (lima) tahun 2011-2015, yaitu pada tahun 2011 biaya beban Rp.188.896.628biaya pemakaian listrik Rp. 27.810.817.224, tahun 2012 biaya beban Rp. 177.664.860biaya pemakaian listrik Rp. 22.688.012.496, tahun 2013 biaya beban Rp. 167.498.025biaya pemakaian listrik Rp. 26.769.037.104, tahun 2014 biaya beban Rp. 169.856.201 biaya pemakaian listrik Rp. 36.329.306.172, tahun 2015 biaya beban Rp. 152.120.205 biaya pemakaian listrik Rp. 37.303.214.916.

Tabel 5.Biaya Beban dan Biaya Pemakaian Listrik Pajak Penerangan Jalan per Golongan Tarif IndustriTahun 2011-2015

\begin{tabular}{lccc}
\hline No & Tahun Anggaran & Biaya Beban $(\mathrm{Rp})$ & Biaya Pemakaian Listrik (Rp) \\
\hline 1 & 2011 & 567.000 & 7.278 .254 .460 \\
\hline 2 & 2012 & 283.500 & 5.940 .222 .948 \\
\hline 3 & 2013 & 283.500 & 9.833 .735 .436 \\
\hline 4 & 2014 & 283.500 & 13.437 .084 .936 \\
\hline 5 & 2015 & 283.500 & 13.535 .075 .721 \\
\hline
\end{tabular}

Sumber: PLN Cabang Amurang 
Dari tabel 5 dapat dilihat biaya beban dan biaya pemakaian listrik pajak penerangan jalan per Golongan tarif Industri selama 5 (lima) tahun 2011-2015, yaitu pada tahun 2011 biaya beban Rp.567.000biaya pemakaian listrik Rp. 7.278.254.460, tahun 2012 biaya beban Rp. 283.500 biaya pemakaian listrik Rp. 5.940.222.948, tahun 2013 biaya beban Rp. 283.500 biaya pemakaian listrik Rp. 9.833.735.436, tahun 2014 biaya beban Rp. 283.500 biaya pemakaian listrik Rp. 13.437.084.936, tahun 2015 biaya beban Rp. 283.500 biaya pemakaian listrik Rp. 13.535.075.721.

\section{Biaya Beban dan Biaya Pemakaian Listrik Pajak Penerangan Jalan Kabupaten Minahasa Tenggara per Golongan Tarif Rumah Tangga, Bisnis, dan Industri}

Untuk mengetahui basis pajak penerangan jalan di Kabupaten Minahasa Selatan dapat dilihat dari data Biaya Beban dan Biaya Pemakaian Listrik Pajak Penerangan Jalan Kabupaten Minahasa Tenggara per Golongan Tarif dalam 5 (lima) tahun terakhir yaitu tahun 2011-2015 yang telah diperoleh peneliti dalam penelitian lapangan di Kantor PLN Cabang Ratahan, yang disajikan dalam tabel berikut ini:

Tabel 6. Biaya Beban dan Biaya Pemakaian Listrik Pajak Penerangan Jalan per Golongan Tarif Rumah Tangga dan Bisnis Tahun 2011-2015

\begin{tabular}{lccc}
\hline No & Tahun Anggaran & Biaya Beban $(\mathrm{Rp})$ & Biaya Pemakaian Listrik $(\mathrm{Rp})$ \\
\hline 1 & 2011 & 122.675 .730 & 10.847 .733 .132 \\
\hline 2 & 2012 & 124.435 .575 & 7.129 .205 .664 \\
\hline 3 & 2013 & 108.060 .125 & 10.362 .218 .684 \\
\hline 4 & 2014 & 101.248 .035 & 14.324 .747 .172 \\
\hline 5 & 2015 & 90.692 .819 & 12.072 .189 .852 \\
\hline Sumber: PLN Cabang Ratahan & &
\end{tabular}

Dari tabel 6 dapat dilihat biaya beban dan biaya pemakaian listrik pajak penerangan jalan per Golongan tarif Rumah Tangga dan Bisnis selama 5 (lima) tahun 2011-2015, yaitu pada tahun 2011 biaya beban Rp.122.675.730 biaya pemakaian listrik Rp. 10.847.733.132, tahun 2012 biaya beban Rp. 124.435.575 biaya pemakaian listrik Rp. 7.129.205.664, tahun 2013 biaya beban Rp. 108.060.125 biaya pemakaian listrik Rp. 10.362.218.684, tahun 2014 biaya beban Rp. 101.248.035 biaya pemakaian listrik Rp. 14.324.747.172, tahun 2015 biaya beban Rp. 90.692 .819 biaya pemakaian listrik Rp. 12.072.189.852.

Tabel 7. Biaya Beban dan Biaya Pemakaian Listrik Pajak Penerangan Jalan per Golongan Tarif Industri Tahun 2011-2015

\begin{tabular}{lccc}
\hline No & Tahun Anggaran & Biaya Beban $(\mathrm{Rp})$ & Biaya Pemakaian Listrik $(\mathrm{Rp})$ \\
\hline 1 & 2011 & 850.500 & 428.635 .860 \\
\hline 2 & 2012 & 850.500 & 796.181 .760 \\
\hline 3 & 2013 & 850.500 & 752.264 .144 \\
\hline 4 & 2014 & 850.500 & 839.806 .644 \\
\hline 5 & 2015 & 850.500 & 913.510 .560 \\
\hline Sumber: PLN Cabang Ratahan & &
\end{tabular}

Dari tabel 7 dapat dilihat biaya beban dan biaya pemakaian listrik pajak penerangan jalan per Golongan tarif Industri selama 5 (lima) tahun 2011-2015, yaitu pada tahun 2011 biaya beban Rp.850.500biaya pemakaian listrik Rp. 428.635.860, tahun 2012 biaya beban Rp. 850.500 biaya pemakaian listrik Rp. 796.181.760, tahun 2013 biaya beban Rp. 850.500 biaya pemakaian listrik Rp. 
753.264.144, tahun 2014 biaya beban Rp. 850.500 biaya pemakaian listrik Rp. 839.806.644, tahun 2015 biaya beban Rp. 850.500 biaya pemakaian listrik Rp. 913.510.560.

\section{Pembahasan}

\section{Perbandingan Realisasi Penerimaan Pajak Penerangan Jalan Minahasa Selatan dan Minahasa Tenggara Tahun 2011-2015.}

Rata-rata realisasi penerimaan pajak penerangan jalandi Kabupaten Minahasa Selatan cenderung lebih besar dibandingkan dengan Kabupaten Minahasa Tenggara.

Tabel 8. Perbandingan Realisasi Penerimaan Pajak Penerangan JalanMinahasa Selatan dan Minahasa Tenggara Tahun 2011-2015

\begin{tabular}{lccc}
\hline Kabupaten & Tahun & Realisasi Penerimaan Pajak & $\begin{array}{c}\text { Rata - rata } \\
\text { Penerangan Jalan }\end{array}$ \\
\hline & & & \\
Minahasa Selatan & 2011 & Rp. 3.340.811.055 & \\
& 2012 & Rp. 3.653.605.865 & Rp. 4 101.178.902 \\
& 2014 & Rp. 4.284.764.894 & \\
2015 & Rp. 4.394.767.360 & \\
\hline & Rp. 4.831.945.337 & \\
Minahasa Tenggara 2013 & & Rp. 1.250.217.261 \\
2014 & Rp. 1.052 .193 .695 & \\
2015 & Rp. 1.032.959.466 & \\
\hline
\end{tabular}

2. Perbndingan Potensi Penerimaan Pajak Penerangan Jalan di Kabupaten Minahasa elatan dan Minahasa Tenggara Tahun 2011-2015.

Tabel 9. Perbandingan Potensi Penerimaan Pajak Penerangan Jalan di Kabupaten Mianahasa Selatan dan Kabupaten Minahasa Tenggara Tahun 20112015

\begin{tabular}{cccc}
\hline Kabupaten & Tahun & $\begin{array}{c}\text { Potensi Penerimaan Pajak } \\
\text { Penerangan Jalan }\end{array}$ & Rata - rata \\
\hline \multirow{4}{*}{ Minahasa Selatan } & 2011 & Rp. 3 527 853 531 & \\
& 2012 & Rp. 2.880.618.380 & \\
& 2013 & Rp. 3.677.055.406 & Rp. 4.155.649.966 \\
& 2014 & Rp. 4.988.653.081 & \\
\hline \multirow{5}{*}{ Minahasa Tenggara } & 2015 & Rp. 5.099.069.434 & \\
& 2011 & Rp. 1.139.989.522 & \\
& 2012 & Rp. 805.067.349 & \multirow{2}{*}{ Rp. 1.180.377.165 } \\
& 2013 & Rp. 1.122 .439 .345 & \\
\hline
\end{tabular}


Sumber: Hasil Pengolahan Data, 2016

Potensi penerimaan pajak penerangan jalan yang digambarkan dalam Tabel 1.5 menunjukkan bahwa rata-rata potensi penerimaan pajak penerangan jalan di kabupaten Minahasa Selatan lebih tinggi dibandingkan dengan kabupaten Minahasa Tenggara.

Hasil penelitian menunjukkan bahwa terdapat perbedaan yang signifikan antara Potensi Pajak Penerangan Jalan antara Kabupaten Minahasa Selatan dengan Kabupaten Minahasa Tenggara. Ini berarti potensi penerimaan Pajak penerangan jalan di dua daerah tersebut memiliki nilai potensi yang berbeda. Rata-rata potensi Pajak Penerangan Jalan dari Kabupaten Minahasa Selatan selama lima tahun adalah sebesar Rp. 4.155.649.966, Sedangkan Kabupaten Minahasa Tenggara sebesar Rp. 1.180.377.165. Hal ini dikarenakan jumlah penduduk dan rumah tangga yang ada di Kabupaten Minahasa Selatan lebih banyak jika dibandingkan dengan Kabupaten Minahasa Tenggara.

\section{Perbandingan Efektivitas Penerimaan Pajak Penerangan Jalan di Kabupaten Minahasa Selatan dan Minahasa Tenggara Tahun 2011-2015.}

\begin{tabular}{cccc}
\multicolumn{4}{l}{$\begin{array}{l}\text { Tabel 10. Perbandingan Efektivitas Penerimaan Pajak Penerangan Jalan } \\
\text { Minahasa Selatan dan Minahasa Tenggara Tahun 2011-2015 }\end{array}$} \\
\hline Kabupaten & Tahun & $\begin{array}{c}\text { \% Efektivitas Penerimaan Pajak } \\
\text { Penerangan Jalan }\end{array}$ & Rata - rata \\
& 2011 & $94,69 \%$ & \\
\hline \multirow{4}{*}{ Minahasa Selatan } & 2012 & $126,83 \%$ & $104,17 \%$ \\
& 2013 & $116,52 \%$ & \\
& 2014 & $88,09 \%$ & $107,51 \%$ \\
Minahasa Tenggara & 2015 & $94,76 \%$ & \\
& 2011 & $73,17 \%$ & \\
& 2012 & $130,69 \%$ & \\
& 2013 & $92,02 \%$ & \\
& 2015 & $78,12 \%$ & \\
\hline
\end{tabular}

Sumber: Hasil Pengolahan Data, 2016

Hasil penelitian menunjukkan tidak ada perbedaan yang signifikan antara efektivitas Pajak Penerangan Jalan antara Kabupaten Minahasa Selatan dengan Kabupaten Minahasa Tenggara. Artinya, Penerimaan pajak penerangan jalan di dua daerah tersebut memiliki nilai efektivitas yang hampir sama. Nilai rata-rata efektivitas Pajak Penerangan Jalan di Kabupaten Minahasa Selatan selama lima tahun adalah sebesar 104,17\%, sedangkan Kabupaten Minahasa Tenggara adalah sebesar 107,51\%. Pencapaian nilai efektivitas yang tinggi tersebut dikarenakan pertimbangan yang baik dalam menentukan target penerimaan Pajak Penerangan Jalan untuk setiap tahunnya.

\section{Kesimpulan}

\section{PENUTUP}

Berdasarkan penelitian yang telah dilakukan dapat diketahui bahwa:

1. Dari hasil perhitungan potensi penerimaan pajak penerangan jalan dapat disimpulkan bahwa di Daerah Minahasa Selatan yang paling besar potensi penerimaannya yaitu di Golongan Tarif Rumah Tangga dan Tarif Bisnis dengan total penerimaan Rp. 15.175.642.382 ini didapat dari penambahan keseluruhan dari tahun 2011 sampai 2015 sedangkan di Minahasa Tenggara Golongan Tarif Rumah Tangga dan Tarif Bisnis dengan total penerimaan Rp. 5.528.320.679 ini didapat dari penambahan keseluruhan dari tahun 2011 sampai 2015. 
2. Efektivitas Pemungutan Pajak Penerangan Jalan di Kabupaten Minahasa Selatan dari tahun 20112015 menunjukkan bahwa pemungutan dan pengelolaan Pajak Penerangan Jalan di Kabupaten Minahasa Selatan setiap tahunnya berubah, dimana tahun 2012 dan tahun 2013 tingkat efektifnya di atas $100 \%$. Tetapi, pada tahun 2011 tingkat efektivitas Pajak Penerangan Jalan tidak efektif karena hanya 94,69\%, pada tahun 2012 tingkat efektivitasnya sebesar 126,83\%, pada tahun 2013 tingkat efektivitasnya sebesar 116,52\% , pada tahun 2014 tingkat efektivitasnya sebesar 88,09\%, pada tahun 2015 tingkat efektivitasnya hanya sebesar 94,76\%.

3. Efektivitas Pemungutan Pajak Penerangan Jalan di Kabupaten Minahasa Tenggara dari tahun 20112015 menunjukkan bahwa pemungutan dan pengelolaan Pajak Penerangan Jalan di Kabupaten Minahasa Tengggara juga berubah setiap tahunnya, dimana pada tahun 2012 dan tahun 2015 tingkat efektifnya di atas 100\%. Tetapi, pada tahun 2011 tingkat efektivitas Pajak Penerangan Jalan tidak efektif karena hanya 73,17\%, pada tahun 2012 tingkat efektivitasnya sebesar $130,69 \%$, pada tahun 2013 tingkat efektivitasnya sebesar 92,02\%, pada tahun 2014 tingkat efektivitasnya sebesar 78,12\%, pada tahun 2015 tingkat efektivitasnya paling tinggi sebesar 163,56\%.

4. Hasil penelitian menunjukkan bahwa terdapat perbedaan yang signifikan antara Potensi Pajak Penerangan Jalan antara Kabupaten Minahasa Selatan dengan Kabupaten Minahasa Tenggara. Ini berarti potensi penerimaan Pajak penerangan jalan di dua daerah tersebut memiliki nilai potensi yang berbeda. Rata-rata potensi Pajak Penerangan Jalan dari Kabupaten Minahasa Selatan selama lima tahun adalah sebesar Rp. 4.155.649.966,Sedangkan Kabupaten Minahasa Tenggara sebesar Rp. 1.180.377.165.

5. Hasil penelitian menunjukkan tidak ada perbedaan yang signifikan antara efektivitas Pajak Penerangan Jalan antara Kabupaten Minahasa Selatan dengan Kabupaten Minahasa Tenggara. Artinya, Penerimaan pajak penerangan jalan di dua daerah tersebut memiliki nilai efektivitas yang hamper sama. Nilai rata-rata efektivitas Pajak Penerangan Jalan di Kabupaten Minahasa Selatan selama lima tahun adalah sebesar 104,17 persen, sedangkan Kabupaten Minahasa Tenggara adalah sebesar 107,51 persen. Pencapaian nilai efektivitas yang tinggi tersebut dikarenakan pertimbangan yang baik dalam menentukan target penerimaan Pajak Penerangan Jalan untuk setiap tahunnya.

\section{Saran}

Berdasarkan kesimpulan dari penelitian ini, maka saran yang dapat diberikan penulis atas potensi penerimaan dan efektivitas atas Pajak Penerangan Jalan di Minahasa Selatan dan Minahasa Tenggara adalah sebagai berikut.

1. Efektivitas penerimaan Pajak Penerangan Jalan di Kabupaten Minahasa Selatan dan Minahasa Tenggara perlu mendapatkan perhatian yang lebih lagi karena belum mampu mengoptimalkan penerimaan pajak dari sektor tersebut, padahal potensi yang dimiliki sangatlah besar.

2. Pemerintah Kabupaten Minahasa Selatan dan Minahasa Tenggara, Dinas Pendapatan Daerah, dan PLN sebaiknya membuat suatu kelompok khusus yang menangani pencurian listrik liar yang mampu mengurangi penerimaan pajak penerangan jalan.

3. Pajak penerangan jalan sebagai salah satu pemasukan daerah terbesar di Kabupaten Minahasa Selatan dan Minahasa Tenggara diharapkan dapat menjadi mobilisator pajak daerah di Kabupaten tersebut, namun kenyataannya pajak penerangan jalan belum optimal

4. Dinas Pengelola Keuangan, Pendapatan dan Aset Daerah (DPPKAD) Kabupaten Minahasa Selatan dan Dinas Pendapatan Daerah (DISPENDA) Kabupaten Minahasa Tenggara harus melakukan koordinasi dengan PT. PLN Persero dalam mengelola Pajak Penerangan Jalan, hal ini bertujuan agar DPPKAD Kabupaten Minahasa Selatan dan DISPENDA Kabupaten Minahasa Tenggara dapat mengetahui berapa besar potensi riil dari Pajak Penerangan Jalan yang dimiliki, agar tidak terjadi kesalahan dalam penetapan target.

\section{DAFTAR PUSTAKA}


Ariyanto, 2005, Ekonomi Pariwisata, Penerbit Rineka Cipta, Jakarta.

Indrakusuma, Arieyani W, 2011. Potensi Penerimaan dan Efektivitas Pajak

Penerangan Jalan di Kota Semarang: Universitas Diponegoro Semarang. Ejurnal Undiphttp://eprints.undip.ac.id/29049/1/JURNAL.pdf Diakses pada 10 Februari 2016

Manongga, Christine, 2014. Efektivitas Pajak Penerangan Jalan Dan Kontribusinya Terhadap Pendapatan Asli Daerah Di Kabupaten Minahasa Utara. ISSN 2303-1174. Universitas Sam Ratulangi. Ejurnal

Unsrat http://download.portalgaruda.org/article.php?article=163651\&val=1025\&title=EFEKTIVITA S\%20PAJAK\%20PENERANGAN\%20JALAN\%20DAN\%20KONTRIBUSINYA\%20TERH ADAP\%20PENDAPATAN\%20ASLI\%20DAERAH\%20DI\%20KABUPATEN\%20MINAHA SA\%20UTARA. Diakses pada 25 Februari 2016

Pemerintah Kab. Minahasa Selatan, (2005). Peraturan Daerah Kabupaten Minahasa Selatan No. 10 Tentang Pajak Penerangan Jalan. Amurang.

Pratama, I Putu, (2014).Perbandingan Tingkat Efisiensi Dan Efektivitas Penerimaan Pajak Hiburan Dinas Pendapatan Kota Denpasar Dan Kabupaten Badung. ISSN: 2302-8556. Universitas Udayana. Ejurnal Unud. http://ojs.unud.ac.id/index.php/Akuntansi/article/view/8831/6615. Diakses pada 20 Maret 2016

Purwasih, Tyas, 2014. Analisis Potensi Penerimaan Dan Efektivitas Pajak Penerangan Jalan di Kabupaten GresikVol. 3 No.1.Universitas Negeri Surabaya.Ejurnal Unesa. http://ejournal.unesa.ac.id/article/13753/57/article.pdf. Diakses pada 20 Maret 2016

Sugiyono, (2011). Metode Penelitian Kualitatif dan R\&D. Penerbit Alfabeta, Bandung

Suwardjono, (2014). Akuntansi Pengantar Bagian 1, Edisi Ketiga, Penerbit BPFE, Yogyakarta.

Sumarsan. 2013. Perpajakan Indonesia, Edisi Ketiga, Penerbit PT. Indeks, Jakarta Barat.

Undang-Undang Nomor 28 Tahun 2009 tentang Pajak Daerah dan Retribusi Daerah

Wurangian, Mario, 2013. Analisis Potensi Pajak Daerah Kabupaten Minahasa. ISSN 2303-1174. Universitas Sam Ratulangi.Ejurnal

Unsrat. http://ejournal.unsrat.ac.id/index.php/emba/article/view/2722 . Diakses pada 1 April 2016

Waluyo, (2011).Perpajakan Indonesia Edisi 10 Buku 1. Penerbit Salemba Empat. Jakarta 